\title{
Cross sectional and longitudinal study on selenium, glutathione peroxidase, smoking, and occupational exposure in coal miners
}

R Nadif, M-P Oryszczyn, M Fradier-Dusch, G Hellier, J-P Bertrand, Q-T Pham, F Kauffmann

\begin{abstract}
Objectives-To understand the variations of selenium (Se) concentration relative to changes in occupational exposure to coal dust, taking into account age and changes in smoking habits in miners surveyed twice, in 1990 and 1994. To better understand the relation of Se concentration with glutathione peroxidase activities (GSHPx) in these miners.

Methods-In 1994, blood samples were obtained from active $(n=131)$ and retired $(n=40)$ miners without coal worker's pneumoconiosis, in whom Se concentration was available at both surveys and in whom International Labour Organisation (ILO) profusion grade had not been changed. Active miners were exposed to high dust concentrations $(n=48)$ or low dust concentrations $(n=83)$. Miners were classified into three subgroups according to their estimated cumulative exposure to dust, and into three subgroups according to their smoking habits.
\end{abstract}

Results-Selenium concentration and GSH-Px activities were significantly lower in active than in retired miners (Se adjusted means: $62.6 v 72.2 \mathrm{ng} / \mathrm{ml} \mathrm{p}=0.01$ ). Moreover, Se concentration was lower in miners exposed to high compared with those exposed to low dust concentrations (adjusted means: $59.4 v 65.8$ ). In miners exposed to high dust concentrations, Se concentration was significantly lower whereas erythrocyte GSH-Px activity was significantly higher in the subgroup with estimated cumulative exposure $>68 \mathrm{mg} /$ $\mathbf{m}^{3}$.y. In all miners, plasma GSH-Px activity was correlated with Se concentration $(r=0.22, p<0.005)$. The 4 year Se changes were negatively related to exposure to high dust concentrations and positively related to change in exposure from high to retirement and to change from smoker to ex-smoker $(\mathrm{p}=0.01)$.

Conclusion-The variations of Se concentration in relation to changes in occupational exposure to coal dust and in smoking habits, and the close correlation found between plasma Se concentration and GSH-Px activity suggest that both are required in antioxidant defence. These results agree well with the hypothesis that the decrease in Se concentration reflects its use against reactive oxygen species generated by exposure to coal mine dust and by smoking.

(Occup Environ Med 2001;58:239-245)

Keywords: antioxidant enzymes; coal miners; dust exposure; selenium; reactive oxygen species

Selenium (Se), one of the essential trace elements, plays a major part in many metabolic functions. Kelly and Brabin ${ }^{1}$ stated that the exact mechanisms of protection by Se are not known, but may be due to $(a)$ a role for Se as an additive in the respiratory microsomal system; (b) the presence of Se leading to a reduction in the in vivo covalent binding of exogenous pollutants to host macromolecules; and (c) the antioxidant action of Se as an integral component of glutathione peroxidase (GSH-Px) which protects against lipid peroxidation and resultant peroxidative damage. Moreover, it is now well established that Se deficiency can lead to several clinical disorders such as heart disease and cancer. ${ }^{2}$

The biological pathways involved in the development of coal workers' pneumoconiosis remain partly unknown. Reactive oxygen species could well play an essential part in this process. ${ }^{3}$ Reactive oxygen species are released during the phagocytosis of inhaled dust particles, ${ }^{45}$ and may be generated from the particles themselves. ${ }^{67}$ The continuous production of reactive oxygen species may overwhelm antioxidant defences, and may result in an oxidative stress leading to cellular damage in the lung. ${ }^{8}$

The presence of Se in the active site of GSH-Px is essential to its function-that is, protecting lipids by removing hydrogen peroxide and phospholipid hydroperoxides generated in vivo by reactive oxygen species-and thus to the antioxidant status of the cell. ${ }^{9}$ Erythrocytes are circulating antioxidant carriers that penetrate lung capillaries and have been shown to play a significant part in protection against lung damage due to reactive oxygen species. ${ }^{10-12}$ To a lesser extent, plasma GSH-Px also provides protection against reactive oxygen species. ${ }^{13}$

A few studies, all cross sectional, have investigated the relations between occupational exposure to dust and blood antioxidants in coal miners. In 1996, an exposure-effect relation between exposure to coal dust and Se concentration was found. ${ }^{14}$ The lowest Se values were found for miners with both long term and cur- 
Miners in whom Se concentrations were available:

At both surveys:

Miners in whom ILO profusion grades had been changed:

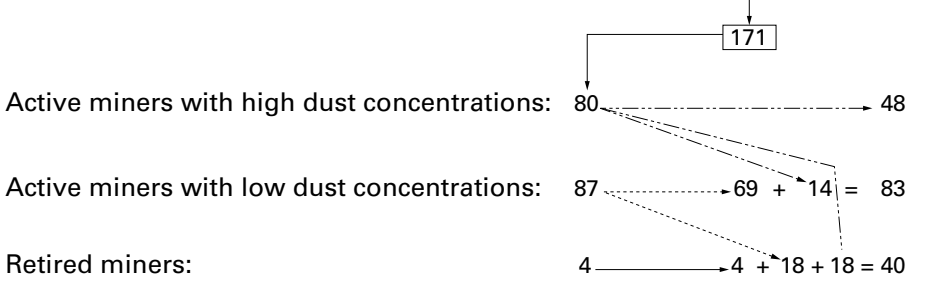

Figure 1 Changes in exposure between 1990 and 1994.

rent exposure, the highest for those never or slightly exposed. More recently, activities of erythrocyte catalase and $\mathrm{Cu}^{++} / \mathrm{Zn}^{++}$superoxide dismutase, two antioxidant enzymes, have been found to be more closely related to recent exposure to high concentrations of coal dust than to cumulative exposure. ${ }^{15}$ Moreover, it was hypothesised that if miners with both long term and current exposure to high dust concentrations were transferred to exposure to low dust concentrations, their antioxidant enzyme activities would return to normal. The purpose of the present study was to understand the variations of $\mathrm{Se}$ concentration relative to changes in occupational exposure to coal mine dust, taking into account age and changes in smoking habits in miners surveyed twice, in 1990 and 1994, and to better understand the relation between $\mathrm{Se}$ concentration and $\mathrm{GSH}-\mathrm{Px}$ activities in these miners.

\section{Materials and methods}

STUDY SAMPLE

This study is part of a larger project in which coal miners of a French coalmine (Houillères du Bassin de Lorraine, in north east France) have been selected according to a detailed protocol previously described. ${ }^{16-18}$ In 1990, the sample consisted of 240 coal miners aged 34-50 years with pulmonary radiographs classified by four independent physicians according to the International Labour Office (ILO) classification of pneumoconioses. ${ }^{19}$ These coal miners were examined in 1990 and in 1994.

Our study sample was composed of miners in whom Se concentrations were available at both surveys and ILO profusion grade had not changed between 1990 and $1994(\mathrm{n}=171)$. In 1990, one group consisted of 80 miners exposed to high dust concentrations for 10 years or more, a second group consisted of 87 miners exposed to low dust concentrations, and a third group consisted of four retired miners. Exposure to dust concentrations changed between the surveys in 50 miners. In 1994, one group consisted of 48 miners exposed to high dust concentrations for 14 years or more, a second group consisted of 83 miners exposed to low dust concentrations for 4 years or more, and a third group consisted of 40 retired miners (figure 1 ).

The examination included a questionnaire on job and medical history, medication, dietary habits, and the questionnaire of the European Community for Steel and Coal on respiratory symptoms, ${ }^{20}$ and smoking habits. The subjects were classified as current smokers if they smoked at the time of the study or had stopped smoking for less than 1 year, as non-smokers if they had never smoked, and as ex-smokers if they had smoked in the past and had stopped smoking for 1 year or more. Cigarette smoking was recorded as the current number of cigarettes smoked a day.

Occupational exposure was defined as exposure to low or high underground concentrations of dust at the time of the study in 1990 and in 1994, and also as individual estimated cumulative exposure to dust in 1994. The subjects were classified as miners exposed to high dust concentrations if they worked at the coal face, mining, stope, or drift advance, and as miners exposed to low dust concentrations if they worked at ventilation maintenance, pumping, haulage, shaft, stock equipment, or safety. Cumulative personal exposure to dust was estimated from each person's job history and from dust measurements at various sites of the coal mine according to the calculation previously described. ${ }^{21}$ The estimates were the summations of each dust measurement $\left(\mathrm{mg} / \mathrm{m}^{3}\right)$ for the respective time spent in each job. Estimated cumulative exposures to dust were calculated until June 1994 and expressed as $\mathrm{mg} / \mathrm{m}^{3}$.y.

This study was approved by the consultative committee for human subject protection in biomedical research of Metz (Lorraine, north east France). Written informed consent was collected from each subject.

\section{BLOOD SAMPLES}

Blood samples were collected into $5 \mathrm{ml}$ Vacutainer tubes containing lithium heparinate as an anticoagulant (Becton Dickinson, USA). On the same day, corresponding plasma samples and haemolysates were prepared as described previously. ${ }^{22}$ Plasma and ghost free haemolysates were stored at $-35^{\circ} \mathrm{C}$.

BIOLOGICAL ASSAYS

Plasma Se concentration was measured by the method of Koh and Benson. ${ }^{23}$ The basis of this method is the reaction of 2.3diaminonaphthalene (DAN) with Se (IV) to form a fluorescent Se-DAN complex. In 1990, all samples were analysed in duplicate (several days apart), but the second measurement was not accurate due to technical problems. In 1994, all samples were analysed in duplicate except for those from 12 miners (lack of plasma). The precision (coefficient of variation) was about $10 \%$. Results were expressed as $\mathrm{ng} / \mathrm{ml}$.

Haemoglobin content $(\mathrm{g} / \mathrm{l})$ was measured in haemolysates by the method of Drabkin and Austin. ${ }^{24}$

The GSH-Px activity was measured at $37^{\circ} \mathrm{C}$ in a Cobas-Mira $\mathrm{S}$ analyser with a Ransell kit (Randox laboratories, Crumlin, UK) by the method of Paglia and Valentine. ${ }^{25}$ The GSH-Px activity was expressed as U/g haemoglobin in erythrocytes, and U/1 in plasma. All samples were analysed in duplicate or triplicate and the 
Table 1 Comparison between active and retired miners in $1994(n=171)$

\begin{tabular}{llll}
\hline & Active miners $(n=131)$ & Retired miners $(n=40)$ & $p$ Value \\
\hline Age (y, mean (SD)) & $45.6(3.2)$ & $49.7(2.0)$ & 0.0001 \\
Estimated cumulative exposure to dust $\left(\mathrm{mg} / \mathrm{m}^{3} . \mathrm{y}\right.$, mean (SD)) & $51.2(41.4)$ & $67.2(44.2)$ & \\
Smoking (\%): & 23 & 25 & 0.04 \\
$\quad$ Non-smokers & 22 & 45 & 0.008 \\
Ex-smokers & 55 & 30 & 0.2 \\
$\quad$ Current smokers & $63.6(19.1)$ & $67.9(15.9)$ & 0.2 \\
Selenium concentration (ng/ml, mean (SD)) & $694(234)$ & $748(227)$ & 0.01 \\
Plasma GSH-Px (U/l, mean (SD)) & $38.8(12.5)$ & $44.6(13.7)$ & 0.01 \\
Erythrocyte GSH-Px (U/g Hb, mean (SD)) & 62.6 & 72.2 & 0.04 \\
Adjusted means: & 680 & 785 & 0.003 \\
$\quad$ Age and smoking adjusted Se concentration (ng/ml) & 38.5 & 46.5 & \\
Age and smoking adjusted plasma GSH-Px (U/l) & & \\
Age and smoking adjusted erythrocyte GSH-Px (U/g Hb) & & \\
\hline
\end{tabular}

precision (coefficient of variation) was $<10 \%$. The accuracy was checked by analysing external reference samples together with the test samples.

STATISTICAL METHODS

All variables presented a normal distribution except age, estimated cumulative exposure to dust $\left(\mathrm{mg} / \mathrm{m}^{3} . \mathrm{y}\right)$, and cigarette smoking (cigarettes/day). Miners were classified into subgroups according to the tertiles of estimated cumulative exposure to dust $(\leqslant 21$ $\left.\mathrm{mg} / \mathrm{m}^{3} . \mathrm{y}, 21-68 \mathrm{mg} / \mathrm{m}^{3} . \mathrm{y},>68 \mathrm{mg} / \mathrm{m}^{3} . \mathrm{y}\right)$. In miners exposed to high dust concentrations and in retired miners, only two subgroups of estimated cumulative exposure to dust were presented due to the few subjects in the first tertile. The homogeneity $\mathrm{X}^{2}$ test was performed to compare the proportions of smokers, non-smokers, and ex-smokers between the groups. For comparison between means, Student's $t$ test and analysis of variance (ANOVA) were used. Means were adjusted for age and smoking habits with the GLM procedure. Paired comparisons were performed with the MEANS procedure. For evaluation of the relations between 4 year Se changes and qualitative variables classified into more than two groups, a trend test was performed with the GLM procedure. For evaluation of the relations between quantitative variables, Pearson's correlation $(r)$ was used.

To describe the associations between 4 year Se changes and changes in exposure and smoking habits, multiple linear regression was used. Age was forced in the model; $F$ tests were used to check the significance of coefficients. The stability of the variance and the approximate linearity were checked on residual plots.

Significance was assessed at the $5 \%$ two sided level. All these analyses were performed with SAS statistical software (SAS Institute, Cary, North Carolina). ${ }^{26}$

\section{Results}

The group in whom Se concentration was not available in 1990, in 1994, or at both surveys, or ILO profusion grade had changed between 1990 and 1994 was composed of 69 miners with a mean (SD) age 46.4 (3.7) in 1994. Thirty five were smokers (55\%). The number of cigarettes they smoked each day in 1990 and in 1994, Se concentration, and GSH-Px activities in 1994 were not significantly different from those of the 171 miners. Their estimated cumulative exposure to dust was slightly higher than those of the 171 miners in 1994 (66.4 (40.8) $v 55.0$ (42.5), $\mathrm{p}=0.06)$ but the proportions of retired miners and active miners with high or low dust exposure, and the proportions of miners in each group with change in exposure, were not significantly different from those of the 171 miners.

CROSS SECTIONAL STUDY

Mean (SD, range) Se concentration was 64.6 $(18.5,25.2-123.6) \mathrm{ng} / \mathrm{ml}$. Some relations were found between age and Se concentration and GSH-Px activities. In miners exposed to high dust concentrations, Se concentration was inversely related to age $(r=-0.36, \mathrm{p}=0.01)$. In retired miners, a negative association was found between the erythrocyte GSH-Px activity and the age of the miners $(r=-0.39$, $\mathrm{p}=0.01)$. Ex-smokers had the highest mean (SD) value of Se concentration (67.8 (18.0) $\mathrm{ng} / \mathrm{ml})$, non-smokers and current smokers had lower values (63.2 (17.7) and 63.4 (19.1), respectively). No other relations were found between Se concentration and GSH-Px activity and dietary habits, alcohol consumption, or medication. As expected, in both groups of

Table 2 Comparison between active miners with high and low dust concentrations in 1994 ( $n=131)$

\begin{tabular}{llll}
\hline & High for $\geqslant 14$ years $(n=48)$ & Low for $\geqslant 4$ years $(n=83)$ & $p$ Value \\
\hline Age (y, mean (SD)) & $45.7(3.4)$ & $45.5(3.1)$ & 0.7 \\
Estimated cumulative exposure to dust $\left(\mathrm{mg} / \mathrm{m}^{3} . \mathrm{y}\right.$, mean (SD)) & $71.8(35.8)$ & $39.3(39.9)$ & 0.0001 \\
Smoking (\%): & 12 & 29 & \\
$\quad$ Non-smokers & 25 & 20 & 0.09 \\
Ex-smokers & 63 & 51 & 0.06 \\
$\quad$ Current smokers & $59.5(18.6)$ & $65.9(19.1)$ & 0.7 \\
Selenium concentration (ng/ml, mean (SD)) & $686(203)$ & $698(251)$ & 0.5 \\
Plasma GSH-Px (U/l, mean (SD)) & $37.9(13.6)$ & $39.3(11.6)$ & 0.06 \\
Erythrocyte GSH-Px (U/g Hb, mean (SD)) & 59.4 & 65.8 & 0.9 \\
Adjusted means: & 682 & 689 & 0.8 \\
$\quad$ Age and smoking adjusted Se concentration (ng/ml) & 39.1 & \\
Age and smoking adjusted plasma GSH-Px (U/1) & & \\
Age and smoking adjusted erythrocyte GSH-Px (U/g Hb) & 38.6 & & 0.8 \\
\hline
\end{tabular}


Table 3 Comparison between subgroups of estimated cumulative exposure to dust in active miners in 1994 ( $n=131)$

\begin{tabular}{|c|c|c|c|c|c|c|c|}
\hline & \multicolumn{3}{|c|}{ High for $\geqslant 14 y$} & \multicolumn{4}{|l|}{ Low for $\geqslant 4 y$} \\
\hline & $\begin{array}{l}>68 \mathrm{mg} / \mathrm{m}^{3} \cdot y \\
(n=19)\end{array}$ & $\begin{array}{l}\leqslant 68 \mathrm{mg} / \mathrm{m}^{3} \cdot y \\
(n=29)\end{array}$ & $p$ Value & $\begin{array}{l}>68 \mathrm{mg} / \mathrm{m}^{3} \cdot y \\
(n=18)\end{array}$ & $\begin{array}{l}21-68 \mathrm{mg} / \mathrm{m}^{3} \cdot y \\
(n=16)\end{array}$ & $\begin{array}{l}\leqslant 21 \mathrm{mg} / \mathrm{m}^{3} \cdot y \\
(n=49)\end{array}$ & $p$ Value \\
\hline Selenium concentration $(\mathrm{ng} / \mathrm{ml}$, mean (SD)) & $52.1(19.0)$ & $64.4(17.0)$ & 0.03 & $61.1(17.9)$ & $62.1(16.8)$ & $68.9(20.1)$ & 0.2 \\
\hline Plasma GSH-Px (U/1, mean (SD)) & $685(185)$ & $687(217)$ & 0.9 & $577(221)$ & $713(166)$ & $739(274)$ & 0.06 \\
\hline Erythrocyte GSH-Px (U/g Hb, mean (SD)) & $43.4(12.6)$ & $34.4(13.4)$ & 0.03 & $39.1(9.9)$ & $40.4(9.1)$ & $38.9(13.3)$ & 0.9 \\
\hline \multicolumn{8}{|l|}{ Adjusted means: } \\
\hline $\begin{array}{l}\text { Age and smoking adjusted Se concentration } \\
(\mathrm{ng} / \mathrm{ml})\end{array}$ & 54.6 & 64.6 & 0.08 & 62.9 & 62.5 & 67.6 & 0.5 \\
\hline $\begin{array}{l}\text { Age and smoking adjusted plasma GSH-Px } \\
(\mathrm{U} / \mathrm{l})\end{array}$ & 704 & 689 & 0.8 & 581 & 705 & 709 & 0.14 \\
\hline $\begin{array}{l}\text { Age and smoking adjusted erythrocyte } \\
\text { GSH-Px }(\mathrm{U} / \mathrm{g} \mathrm{Hb})\end{array}$ & 45.6 & 35.6 & 0.02 & 39.5 & 39.8 & 38.7 & 0.9 \\
\hline
\end{tabular}

active miners, the estimated cumulative exposure to dust was positively related to age $(r=0.37, \mathrm{p}<0.005 ; r=0.32, \mathrm{p}=0.02)$. In all miners, the number of cigarettes smoked a day was negatively related to the estimated cumulative exposure to dust $(r=-0.33, \mathrm{p}<0.005)$ and age $(r=-0.22, \mathrm{p}<0.05)$.

A comparison of active and retired miners in 1994 showed significant differences for age, estimated cumulative exposure to dust, and smoking habits (table 1). Selenium concentration and plasma GSH-Px activity in the group of active miners did not differ significantly from those measured in the group of retired miners whereas erythrocyte GSH-Px activity was significantly lower in the group of active miners. After adjustment for age and smoking, Se concentration and GSH-Px activities were significantly lower in the group of active miners.

A comparison of active miners with high and low dust concentrations in 1994 showed differences for estimated cumulative exposure to dust and smoking habits (table 2). Moreover, the number of cigarettes smoked a day was significantly lower in the group of miners with high dust concentrations (12.9 (5.7) $v 17.4$ (8.7), $\mathrm{p}=0.01)$. Selenium concentration was lower in the group of miners with high dust concentrations whereas GSH-Px activities did not differ significantly between the groups (even after adjustment for age and smoking habits).

A comparison of $\mathrm{Se}$ concentration and GSH-Px activities between the subgroups of estimated cumulative exposure to dust showed several significant differences only in active miners (table 3). In miners exposed to high dust concentrations, Se concentration was significantly lower whereas erythrocyte GSH-Px activity was significantly higher in miners with estimated cumulative exposure to dust $>68$ $\mathrm{mg} / \mathrm{m}^{3} . \mathrm{y}$. The difference remained significant for erythrocyte GSH-Px in an analysis of covariance with age and smoking habits as the covariates. In miners exposed to low dust concentrations, plasma GSH-Px activity decreased significantly with the group of estimated cumulative exposure to dust (trend test, $\mathrm{p}=0.02$ ). In retired miners, even if Se concentration was lower in miners with estimated cumulative exposure to dust $>68 \mathrm{mg} / \mathrm{m}^{3}$.y, no significant difference was found, even after adjustment for age and smoking (data not shown).

In all miners, plasma GSH-Px activity was positively related to erythrocyte GSH-Px activity $(r=0.54, \mathrm{p}=0.0001)$, and was positively related to Se concentration $(r=0.22, \mathrm{p}<0.005)$. According to the classification of occupational exposure to dust, positive associations were found between plasma GSH-Px activity with erythrocyte GSH-Px activity and Se concentration in miners exposed to high dust concentrations $(r=0.62, \mathrm{p}<0.005 ; r=0.27, \mathrm{p}=0.06$ respectively), in miners exposed to low dust concentrations $\quad(r=0.49, \quad \mathrm{p}<0.005 ; \quad r=0.13$, $\mathrm{p}=0.02$ respectively), and in retired miners $(r=0.56, \mathrm{p}<0.005 ; r=0.36, \mathrm{p}=0.02$ respectively). If miners were classified into three subgroups according to the tertiles of Se concentration, a positive and significant correlation was found with both GSH-Px activities only in the third tertile, in which Se concentrations were $\geqslant 72.9 \mathrm{ng} / \mathrm{ml}$ (data not shown).

\section{LONGITUDINAL STUDY}

Selenium concentration in 1990 was positively correlated with Se concentration in 1994 in all miners $(r=0.34, \mathrm{p}=0.0001)$.

Table 4 shows the results of the 4 year Se changes reported by subgroups of exposure to dust in all miners. A significant increase in Se concentration was found in miners exposed to

Table 4 Selenium concentration, and 4 year Se changes reported by subgroups of exposure to dust in all miners ( $n=171)$

\begin{tabular}{|c|c|c|c|c|c|}
\hline \multirow[b]{2}{*}{ Occupational exposure to dust } & \multirow[b]{2}{*}{$n$} & \multicolumn{2}{|c|}{ Se concentration $(\mathrm{ng} / \mathrm{ml})$} & \multirow{2}{*}{$\begin{array}{l}1994 \mathrm{Se}-1990 \mathrm{Se} \\
(\mathrm{ng} / \mathrm{ml})\end{array}$} & \multirow[b]{2}{*}{ p Valu } \\
\hline & & In 1990 & In 1994 & & \\
\hline \multicolumn{6}{|l|}{ 1990-4: } \\
\hline High $\rightarrow$ high & 48 & $63.5(10.6)$ & $59.5(18.6)$ & $-3.9(18.5)$ & 0.14 \\
\hline High $\rightarrow$ low & 14 & $58.6(11.4)$ & $63.3(20.4)$ & $4.6(12.1)$ & 0.17 \\
\hline High $\rightarrow$ none (retired) & 18 & $64.0(10.8)$ & $70.2(11.4)$ & $6.1(12.6)$ & 0.05 \\
\hline Low $\rightarrow$ low & 69 & $64.4(10.9)$ & $66.4(19.0)$ & $2.0(18.0)$ & 0.3 \\
\hline Low $\rightarrow$ none (retired) & 18 & $66.4(10.4)$ & $64.4(15.9)$ & $-2.0(20.3)$ & 0.6 \\
\hline None (retired) $\rightarrow$ none (retired) & 4 & $65.6(7.0)$ & $72.9(31.2)$ & $7.3(30.3)$ & 0.6 \\
\hline
\end{tabular}

Results are expressed as mean (SD). 
Table 5 Factors associated with 4 year Se changes in all miners $(n=171)$

\begin{tabular}{lrl}
\hline & Coefficient (SD) & p Value \\
\hline Change in occupational exposure: & $-6.80(3.23)$ & 0.04 \\
High $\rightarrow$ high & $2.41(5.14)$ & 0.6 \\
High $\rightarrow$ low & $8.43(4.94)$ & 0.08 \\
High $\rightarrow$ none (retired) & $-1.95(4.99)$ & 0.7 \\
Low $\rightarrow$ none (retired) & 0.0 & \\
Reference category: low or none (retired) at both surveys & & \\
Change in smoking habits: & $4.12(3.03)$ & 0.17 \\
Smoker $\rightarrow$ smoker & $9.12(5.48)$ & 0.09 \\
Smoker $\rightarrow$ ex-smoker & $2.02(6.60)$ & 0.7 \\
$\quad$ (Ex-smoker or non-smoker) $\rightarrow$ smoker & $-12.71(5.67)$ & 0.02 \\
$\quad$ Ex-smoker $\rightarrow$ non-smoker) or (non-smoker $\rightarrow$ ex-smoker) & 0.0 & \\
Reference category: ex-smoker or non-smoker at both surveys & $-0.71(0.44)$ & 0.10 \\
Age (y) & & \\
\hline
\end{tabular}

high dust concentrations in 1990 and retired in $1994(n=18)$. An increase was also found in miners exposed to high dust concentrations in 1990 and exposed to low dust concentrations in $1994(n=14)$. By contrast, a decrease was found in miners exposed to high dust concentrations at both surveys $(n=48)$. Moreover, the difference in Se concentration was positively and significantly related to the degree of the change in occupational exposure of miners exposed to high concentrations in 1990 (trend test, $\mathrm{p}=0.02$ ).

Table 5 shows the results of the multiple linear regression and indicates the associations between 4 year changes in Se concentration and changes in exposure to dust and smoking habits in all miners. Changes in Se from 1990 to 1994 was negatively and significantly related to exposure to high dust concentrations and positively related to change in exposure from high to no exposure (retirement). Changes in Se were also positively related to the change from smoker to ex-smoker, and was negatively and significantly related to the change from ex-smoker to non-smoker or non-smoker to ex-smoker.

\section{Discussion}

In this study, we found that the variation in Se concentration was related to the changes in occupational exposure to coal mine dust and smoking. To our knowledge, this longitudinal study is the first to describe associations between changes, from exposure to retirement and stopping smoking, and an increase in $\mathrm{Se}$ concentration in coal miners. This study extends previous knowledge ${ }^{14}$ and better shows the effect of exposure to coal dust on $\mathrm{Se}$ concentration.

Selenium concentrations found in our sample study agree with reference values for $\mathrm{Se}$ in a French population $(50-110 \mathrm{ng} / \mathrm{ml}){ }^{27}$ The north east of France, where the study took place, is a region with low Se concentration, but our values are slightly lower (around 60 $\mathrm{ng} / \mathrm{ml}$ ) than the concentration found (by another method) in healthy adults studied in the same region (around $80 \mathrm{ng} / \mathrm{ml}$ ). ${ }^{28}$ The significant relations between $\mathrm{Se}$ concentration and age and smoking showed good agreement with the results we found in $1990^{14}$ and in other studies. ${ }^{29-31}$ In 1990, we found that Se concentration decreased significantly with age and smoking, with a decrease of $7 \%$ from the youngest to the oldest age group, and ex- smokers had the highest value and current smokers had the lowest. Similarly, Lloyd et al ${ }^{9}$ found a significant negative effect of age and smoking on Se in 391 apparently healthy subjects resident in the south of England. Berr et $a l^{30}$ have also found that plasma Se concentration decreased significantly with age in elderly people and Viegas-Crespo et $a l^{1}$ found a strongly significant difference in serum Se concentrations between male smokers and nonsmokers, with the lowest value found in smokers in a Lisbon population.

Results reported in this study support the hypothesis of a causative role for coal mine dust in modifying Se concentration. Firstly, there is a difference in Se concentration between exposed and non-exposed miners. Secondly, an exposure-effect relation between exposure to coal mine dust and Se concentration was found, with the most exposed miners having the lowest Se concentration. Finally, and fortunately, this situation is reversible, as in miners who retired from exposure to high dust concentrations, Se concentration increased. The results found in this study are relevant to those reported previously in the same study sample. ${ }^{15}$ Erythrocyte catalase and $\mathrm{Cu}^{++} / \mathrm{Zn}^{++}$ superoxide dismutase, two antioxidant enzymes were found to be closely related to recent exposure to high coal dust concentrations. These previous results have permitted us to hypothesise that, if miners exposed to high dust concentrations are transferred to low dust concentrations, their catalase and superoxide dismutase activities will return to normal. That was our finding in the present study for Se concentration in miners exposed to high dust concentrations in 1990 and retired in 1994.

There have been few studies reporting the Se concentration and GSH-Px activities of industrial workers but our findings are in agreement with most of them. Lane et $a l^{\beta 2}$ reported that plasma and erythrocyte Se concentrations and erythrocyte GSH-Px in oil refinery workers in Texas were significantly lower than those in controls in the same region. Similar low Se concentrations, with low blood GSH-Px activities, were also reported in power station and rubber factory workers in Poland. ${ }^{33}$ Yoshida et $a l^{34}$ reported that both plasma and erythrocyte Se concentrations in 47 healthy Japanese male workers handling aromatic nitroamino compounds routinely showed $20 \%$ lower values than those in 107 non-industrial healthy men with the same age and living in the same geographical area. Similar to the Se concentration, the GSH-Px activities were significantly decreased in the exposed workers, but the extent of decrease was different between plasma and erythrocytes; the plasma GSH-Px activity was decreased $27 \%$ whereas the erythrocyte activity was decreased $13 \%$. By contrast, Barregard et al, ${ }^{35}$ who measured the plasma Se concentrations of 37 male chloralkali workers exposed to mercury vapours and 39 age matched non-exposed workers in the same company, reported that, even if the plasma Se concentration and GSH-Px activity were slightly lower in the exposed group, they did not differ between the groups. The authors 
explained this lack of significant difference by a long term but moderate exposure to inorganic mercury. Only one study reported a difference in Se concentration between exposure groups. Gromadzinska et $a l^{\beta 6}$ showed that tanners working in areas with high chromium concentrations had a significant decrease in plasma Se concentration compared with other tanners. Workers were aged $22-55$ and were exposed to different concentrations of chromium compounds for 3-16 years. Selenium concentration was also measured in a control group consisting of 104 healthy residents 17-69 years of age who were not employed in industry. Selenium concentration was negatively related to exposure to chromium concentration and blood $\mathrm{Se}$ concentration was positively correlated with erythrocyte GSH-Px activity.

Oxidative stress may be responsible for the low Se concentration in the exposed workers. Aromatic nitroamino compounds, inorganic mercury, and chromium compounds have oxidative stress properties. Similarly, chronic exposure to and inhalation of coal mine dust particles increase the production of reactive oxygen species. As proposed by Kelly and Brabin $^{1}$ if the decrease in Se concentration we reported here reflects the antioxidant action of $\mathrm{Se}$ as an integral component of GSH-Px, then the negative association between Se concentration and occupational exposure to coal dust must be concomitant with a positive association between GSH-Px activity and occupational exposure to coal dust. If so, we should have found no association or a negative association between Se concentration and GSH-Px activity. In fact, a concomitant negative association between Se concentration and GSH-Px activity and occupational exposure, and a positive association between plasma Se concentration and GSH-Px activity were reported in this study. Two hypotheses may be proposed to explain our results as well as those already mentioned. The first is that Se might be required for another selenoprotein, called selenoprotein $\mathrm{P}$, which differs from GSH-Px and may be involved in antioxidant defence. ${ }^{37} 38$ However, the hypothesis of oxidative stress is more probable and is emphasised by the positive association between Se concentration and GSH-Px activity. A similar association has been reported by some authors but not by others. Ceballos-Picot et $a^{39}$ reported a high correlation $(r=0.54, \mathrm{p}<0.01)$ between plasma Se concentration and GSH-Px activity in 34 elderly French patients with Se concentrations less than $72 \mathrm{ng} / \mathrm{ml}$. A high correlation $(r=0.82$, $\mathrm{p}<0.001$ ) was also found between plasma Se concentration and GSH-Px activity in 14 patients in Italy. ${ }^{40}$ By contrast, Matsuda et $a l^{41}$ found no correlation between plasma $\mathrm{Se}$ concentration and GSH-Px activity in healthy Japanese adults with Se concentrations greater than $77 \mathrm{ng} / \mathrm{ml}$. According to many epidemiological studies, ${ }^{42-46}$ there is a close correlation between Se concentration and GSH-Px activity below a threshold value of Se concentration around $70 \mathrm{ng} / \mathrm{ml}$. Below this value, a correlation exists showing that GSH-Px activity is dependent on Se; above this concentration, the association shows a plateau indicating that the Se requirement for the function of GSH-Px is satisfied. Thus, for plasma Se concentration lower than $77 \mathrm{ng} / \mathrm{ml}$, Berr et $a l^{30}$ found a strong correlation between Se concentration and GSH-Px activity in a representative sample of non-institutionalised people aged 65 or more living in south western France. Above this value, the correlation decreased and the authors suggested that the Se requirement for synthesis of GSH-Px had been satisfied. In our study, not only did we find a correlation between Se concentration and GSH-Px activity in all miners and in the three subgroups of occupational exposure to dust with Se concentration from 25 to $127 \mathrm{ng} / \mathrm{ml}$, but in the subgroup with Se concentrations over $73 \mathrm{ng} / \mathrm{ml}$ when miners were classified according to the tertiles of Se concentration. One of the possible explanations of our unexpected results is that in coal miners, who are not representative of the general French population, only a small proportion of plasma Se concentration is associated with GSH-Px below the value of 73 $\mathrm{ng} / \mathrm{ml}$ because it is involved in antioxidant defence. Thus, in miners with Se concentrations lower than $73 \mathrm{ng} / \mathrm{ml}$, the available Se concentration may not be enough for synthesis of the relevant GSH-Px and so we found low plasma GSH-Px activity. In miners with high Se concentration, even if one part is required for antioxidant defence, the available $\mathrm{Se}$ concentration is enough for synthesis of the relevant GSH-Px and we found high plasma GSH-Px activity and an association between the two biological variables.

All our results suggest that in miners with naturally low Se concentration, both $\mathrm{Se}$ and GSH-Px may be not able to protect against damage from reactive oxygen species. Decreased Se concentration found in miners exposed to high dust concentrations may reflect its increased demand in antioxidant defence. It can be hypothesised that this decrease in Se concentration is followed by a decrease in GSH-Px activity, leading to cellular damage in the lung, and if antioxidant defences are overwhelmed, to the development of coal worker's pneumoconiosis.

In conclusion, the relation between $\mathrm{Se}$ concentration and occupational exposure to coal mine dust, and the close correlation found between plasma Se concentration and GSH-Px activity reported in this study suggest that both are required in antioxidant defence. As it is now well established that smoking generates reactive oxygen species, all our results support the role of Se itself in antioxidant defence. These results agree well with the hypothesis that the decrease in Se concentration reflects its use against reactive oxygen species generated by exposure to coal mine dust and by smoking.

We acknowledge the medical staff and all the French coal mine workers who made this study possible. We are grateful to Anne Bara for revising the document. This research was, in part, supported by grant numbers 7280.03 .001 and 7280.03 .035 from the European Community of Steel and Coal.

1 Kelly YJ, Brabin BJ. Do antioxidants matter for asthmatics? Clin Asthma Rev 1997;1:145-52. 
2 Michelson AM. Selenium glutathione peroxidase: some aspects in man. F Environ Pathol Toxicol Oncol 1998;17:2339 .

3 Doelman CJA, Leurs R, Oosterom WC, et al. Mineral dust exposure and free radical-mediated lung damage. Exp Lung Res 1990;16:41-55.

4 Malech HL, Gallin JI. Neutrophils in human diseases. $N$ Engl F Med 1987;317:687-94.

5 Wallaert B, Lasalle P, Fortin F, et al. Superoxide anion generation by alveolar inflammatory cells in simple pneumoconiosis and in progressive massive fibrosis of non smoking coal workers. Am Rev Respir Dis 1990;141:129-33.

6 Berg I, Schlüter T, Gercken G. Increase of bovine alveolar macrophage superoxide anion and hydrogen peroxide release by dusts of different origin. $\mathcal{7}$ Toxicol Environ Health 1993;39:341-54.

7 Petit JC, Boettner JC. Evidence of $\mathrm{H}_{2} \mathrm{O}_{2}$ formation in the early stage of coal oxidation. In: Charcosset $\mathrm{H}$, ed. Advanced methodologies in coal characterisation. Amsterdam: Advanced methodologies in

8 Sies H. Oxidative stress. London: Academic Press, 1985.

9 Gamble SC, Wiseman A, Goldfarb PS. Selenium$\underset{\text { dependent }}{\text { Gamble SC, Wiseman A, Goldfarb PS. Selenium- }}$ dependent glutathione peroxidase and other Selenoproteins: their synthesis and bioc

10 Toth KM, Clifford DP, Berger EM, et al. Intact human erythrocytes prevent hydrogen peroxide-mediated damage to isolated perfused rat lungs and cultured bovine pulmonary artery endothelial cells. $\mathcal{F}$ Clin Invest $1984 ; 74$ $292-5$

11 Van Asbeck BS, Hoidal J, Vercelotti GM, et al. Protection against lethal hyperoxia by tracheal insufflation of erythrocytes: Role of red cell glutathione. Science 1984;277: erythrocyt $756-8$.

12 Agar NS, Sadrzadeh SMH, Hallaway PE, et al. Erythrocyte catalase: a somatic oxidant defence. $\mathcal{F}$ Clin Invest 1986;77: 319-21.

13 Halliwell B, Gutteridge JMC. Protection against oxidants in biological systems: the superoxide theory of oxygen toxicity. In: Halliwell B, Gutteridge JMC, in biology and medicine, 2 nd rev ed. New York: Oxford Uni9:86-187.

14 Nadif R, Bourgkard E, Dusch M, et al. Relations between occupational exposure to coal mine dusts, erythrocyte catalase and $\mathrm{Cu}^{++} / \mathrm{Zn}^{++}$superoxide dismutase activities, and the severity of coal worker's pneumoconiosis. Occup Environ Med 1998;55:533-40.

15 Oryszczyn MP, Godin J, Frette C, et al. Decrease in selenium status in relation to coal dust exposure. Am f Ind Med 1996;30:281-4.

16 Caillier I, Bruant A, Mahieu B, et al. Constitution d'un échantillon de sujets à l'aide d'une étude de concordance inter-observateurs. Application a des mineurs suspects de pneumoconiose. Arch Mal Prof 1991;52:541-7.

17 Rebstock-Bourgkard E, Chau N, Caillier I, et al. Symptômes et fonction respiratoires des mineurs de charbon présentant des anomalies radiologiques pulmonaires. Rev Epidemiol Santé Publ 1994;42:533-41.

18 Pham QT, Bourgkard E, Chau N, et al. Forced oscillation technique (FOT): a new tool for epidemiology of technique (FOT): a new tool for epidemiology of

9 International Labour Office. Guidelines for the use of ILO international classification of radiographs of pneumoconiosis. Geneva: Occupational Safety and Health Sciences, 1980 22.

20 Minette A. Questionnaire of the European Community for Steel and Coal (ECSC) on respiratory symptoms. Eur Respir F 1989;2:165-77.

21 Attfield MD, Morring K. The derivation of estimated dust exposures for US coal miners working before 1970. Am Ind Hyg Assoc 7 1992;53:248-55.

22 Perrin R, Briançon S, Jeandel C, et al. Blood activity of $\mathrm{Cu} / \mathrm{Zn}$ superoxide dismutase, glutathione peroxidase and catalase in Alzheimer's disease: a case-control study. Gerontology 1990;36:306-13.

23 Koh TS, Benson TH. Critical re-appraisal of fluorometric method for determination of selenium in biological materials. F Assoc Off Angl Chem 1983;66:918-26.

24 Drabkin DL, Austin JH. Spectrophotometric studies: preparation from washed blood cells, nitric oxide haemoglobin and sulfhaemoglobin. F Biol Chem 1935;112:51-65.
25 Paglia DE, Valentine WN. Studies on the qualitative and quantitative characterization of erythrocyte glutathione quantitative characterization of erythrocyt
peroxidase. F Lab Clin Med 1967;70:158-69.

26 SAS Institute. SAS/stat user's guide, version 6.12. Cary, North Carolina: SAS, 1998.

27 Neve J, Therond P. Le sélenium. In: Chappuis P, ed. Les oligoelements en médecine et biologie. Paris: Lavoisier, 1991: 425-57.

28 Dubois F, Teby A, Belleville F, et al. Common values of serum selenium in population in Eastern France. Ann Biol Serum selenium in p

29 Lloyd B, Lloyd RS, Clayton E. Effect of smoking, alcohol, and other factors on the selenium status of a healthy population. F Epidemiol Community Health 1983;37:213-7.

30 Berr C, Nicole A, Godin J, et al. Selenium and oxygen metabolizing enzymes in elderly community residents: a pilot epidemiological study. F Am Geriatr Soc 1993;41:1438.

31 Viegas-Crespo AM, Pavao ML, Santos V, et al. Selenium status and cardiovascular risk factors in populations from different Portuguese regions. In: Kumpulainen JT, Salonen JT, eds. Natural antioxidants and food quality in atherosclerosis and cancer prevention. Cambridge: Royal Society of Chemistry, 1996:188-94.

32 Lane HW, Warren DC, Martin E, et al. Selenium status of industrial workers. Nutr Res 1983;3:805-15.

33 Zachara BA, Wasowicz W, Sklodowska M, et al. Selenium status, lipid peroxides concentration, and glutathione peroxidase activity in the blood of power station and rubber factory workers. Arch Environ Health 1987;42:223-9.

34 Yoshida M, Sunaga M, Hura I. Selenium status in workers handling aromatic nitro-amino compounds in a chemical factory. $₹$ Toxicol Environ Health 1990;31:1-10.

35 Barregard L, Thomassen Y, Schutz A, et al. Levels of selenium and antioxidative enzymes following occupational exposure to inorganic mercury. Sci Total Environ 1990;99: 37-47.

36 Gromadzinska J, Wasowicz W, Sklodowska M, et al. The influence of atmospheric chromium on selenium content and glutathione peroxidase activity in blood of tannery workers. Environ Health Perspect 1996;104:1312-6.

37 Akesson B, Bellew T, Burk RF. Purification of selenoprotein P from human plasma. Biochim Biophys Acta 1994;1204: 243-9.

38 Akesson B, Huang W, Persson-Moschos M, et al. Glutathione peroxidase, selenoprotein $\mathrm{P}$ and selenium in serum of elderly subjects in relation to other biomarkers of nutritional status and food intake. Nutr Biochem 1997;8: 508-17.

39 Ceballos-Picot I, Merad-Boudia M, Nicole A, et al. Peripheral antioxidant enzyme activities and selenium in elderly subjects and in dementia of Alzheimer's type: place of the extracellular glutathione peroxidase. Free Rad Biol Med 1996;20:579-87.

40 Perona G, Cellerino R, Guidi GC, et al. Erythrocyte glutathione peroxidase: its relationship to plasma selenium in man. Scand f Haematol 1977;19:116-20.

41 Matsuda A, Kimara M, Itokawa Y. Selenium level and glutathione peroxidase activity in plasma, erythrocytes and platelets of healthy Japanese volunteers. F Nutr Sci Vitaminol (Tokyo) 1997;43:497-504.

42 Neve J. Physiological and nutritional importance of selenium. Experientia 1991;47:187-93.

43 Rea HM, Thomson CD, Campbell DR, et al. Relation between erythrocyte selenium concentrations and glutathione peroxidase (EC 1.11.1.9) activities of New Zealand residents and visitors to New Zealand. Br $\mathcal{F}$ Nutr 1979;42: 201-8.

44 Butler JA, Thomson CD, Whanger PD, et al. Selenium distribution in blood fractions of New Zealand women taking organic or inorganic selenium. Am f Clin Nutr 1991;53: $748-54$

45 Neve J, Vertongen F, Peretz A, et al. Valeurs usuelles du sélénium et de la glutathion peroxydase dans une population belge. Ann Biol Clin (Paris) 1989;47:138-43.

46 Smith DK, Teague RJ, McAdam PA, et al. Selenium status of malnourished hospital patients. I Am Coll Nutr $1986 ; 5: 243-52$ 